\title{
PENGARUH APLIKASI BIOCOCOTIN TERHADAP PERTUMBUHAN DAN HASIL TANAMAN SAWI PADA TANAH PASIR PESISIR PANTAI
}

\author{
Anandyawati ${ }^{1 *}$, Merlian Zikri², Eko Sumartono ${ }^{3}$, Ridha Rizki Novanda ${ }^{3}$, \\ Amir Husaini Karim Amrullah ${ }^{4}$, Ari Anggoro ${ }^{5}$ \\ ${ }^{1}$ Prodi Ilmu Tanah, Fakultas Pertanian, Universitas Bengkulu \\ ${ }^{2}$ Dinas Pertanian dan Perikanan Kabupaten Lebong, Bengkulu \\ ${ }^{3}$ Jurusan Sosial Ekonomi Pertanian, Fakultas Pertanian, Universitas Dehasen \\ ${ }^{4}$ Jurusan Peternakan, Fakultas Pertanian, Universitas Bengkulu \\ ${ }^{5}$ Prodi Ilmu Kelautan, Fakultas Pertanian, Universitas Bengkulu \\ *email : anandyawati@unib.ac.id; mobile : +6281267410255
}

\begin{abstract}
ABSTRACK
The great potential in coastal sandy lands is followed by various problems and limiting factors that cause the acceleration of land use for agricultural purpose run very slowly. To overcome these limiting factors, appropriate modification and implementation of innovation is needed, namely the providing of soil conditioning materials, such as organic matter. One source of organic material that is still very rarely used, affordable, easy and cheap and simple in its application is the waste of coconut powder and human waste which we call biococotin. Providing of biococotin in coastal sandy lands decreases basic $\mathrm{pH}$ near neutral, increasing levels of $\mathrm{N}, \mathrm{P}, \mathrm{K}, \mathrm{C}$-Organic and cation exchange capacity has decreased from 7.20 to $6.40 \%$. N levels increased from $0.021 \%$ to $0.17 \%$, P-available increased from $2.52 \mathrm{ppm}$ to $20.13 \mathrm{ppm}, \mathrm{K}$ levels increased from $2.52 \mathrm{cmol}^{(+)}$to $9.35 \mathrm{cmol}^{(+)}$and CEC increased from 4, $04 \mathrm{cmol}^{(+)} / \mathrm{kg}$ becomes $7.07 \mathrm{cmol}^{(+)} / \mathrm{kg}$. The best growth parameters (plant height, number of leaves, longest leaf length and longest leaf width) are shown by treatment 2 which is half the dose of NPK and biococotin. The best average planting weight and yield per ha is shown by treatment 2, which is half the dose of NPK and biococotin, which is 44.03 grams / plant and 26.41 tons / ha bicocotin.
\end{abstract}

Keywords : Biococotin, Coastal area, Cocopeat

(c) 2020 Anandyawati, Zikri, Sumartono, Novanda, Amrullah, dan Anggoro.

\section{PENDAHULUAN}

Pemenuhan permintaan sawi di dalam negeri menghadapi berbagai kendala, terutama penurunan luas panen akibat alih fungsi lahan. Berdasarkan data Kementerian Pertanian (2015), alih fungsi lahan dalam kurun 10 tahun terakhir dari lahan produktif ke lahan nonproduktif tercatat sekitar $100.000 \mathrm{ha} /$ tahun. Untuk menghadapi hal tersebut perlu dilakukan pembukaan lahan-lahan pertanian baru dan lahan yang luas dan potensial untuk dijadikan kawasan pertanian baru adalah lahan-lahan marjinal seperti hamparan lahan kering, tanah masam dan tanah pasir pesisir pantai yang belum tersentuh teknologi pertanian.

Lahan pasir pesisir pantai Indonesia tercatat seluas $1,060,000$ ha dengan garis pantai mencapai $95,161 \mathrm{~km}$ yang tersebar 
di berbagai wilayah di Indonesia (Lasabuda, 2013). Salah satu provinsi yang memiliki potensi pengembangan lahan pasir pesisir pantai untuk sektor pertanian hortikultura adalah provinsi Bengkulu dengan garis pantai mencapai $\pm 525 \mathrm{~km}$ (Pemerintah Provinsi Bengkulu, 2015). Potensi yang besar pada lahan pasir pesisir pantai diikuti oleh berbagai permasalahan dan faktor penghambat yang menyebabkan percepatan pendayagunaan lahan untuk budidaya pertanian berjalan sangat larnbat.

Tanah pasir pesisir pantai memiliki berbagai faktor penghambat dari berbagai sifat biologi, fisika dan kimia. Cornell et al., 2003). Faktor penghambat dari sifat biologi adalah kandungan bahan organik yang rendah (Shi et al, 2005). Keberadaan bahan organik di dalarn tanah sangat penting dalam meningkatkan dan mernpertahankan kesuburan tanah, rnelalui perbaikan sifar-sifat fisika, kirnia, dan biologi tanah serta perbaikan lingkungan turnbuh (Aqil, 2002).

Sifat fisik tanah pasir pesisir pantai memiliki berbagai macam penghambat. Antara lain : buruknya tekstur tanah, karena kandungan pasir yang tinggi, sangat rendahnya kemampuan memfiksasi air karena porositas yang tinggi dan luas permukaan yang rendah, tingginya tingkat infiltrasi, laju perkolasi dan infiltrasi serta pengaruh dari kondisi iklim mikro tanah pasir yang ekstrim (Sitorus et al,., 2008; Sumardi, 2008; Shi et al, 2005). Faktor penghambat dari sifat kimia antara lain adalah kandungan unsur hara makro yang rendah (N-total sebesar 0,02-0,08\%, P-total sebesar 100-150 ppm dan K sebesar 0,090,2 cmol/kg) (DPU Provinsi DIY, 2000), rendahnya kemampuan tanah menukarkan kation-kation, kadar karbon organik dan kalsium $(\mathrm{Ca})$ yang sangat rendah (Rajiman et al., 2008).
Pemanfaatan lahan pasir pesisir pantai telah dikembangkan oleh kelompok petani hortikultura di Kota Bengkulu tepatnya di Kelurahan Lempuing, Kecamatan Ratu Agung. Komoditas hortikultura yang paling banyak dikembangkan antara lain adalah : sawi, kangkung, bayam dan kucai. Untuk mengatasi faktor-faktor pembatas dan meningkatkan hasil produksi dari lahan pasir ini, petani memberikan input yang besar, sehingga biaya produksi yang dikeluarkan petani menjadi lebih besar.

Untuk mengatasi faktor-faktor pembatas diperlukan modifikasi dan implementasi inovasi yang tepat guna yaitu pemberian bahan pengkondisi tanah, seperti bahan organik. Salah satu sumber bahan organik yangmasih sangat jarang dimanfaatkan, terjangkau, mudah dan murah serta sederhana dalam pengaplikasiannya adalah limbah serbuk kelapa (cocopeat) dan kotoran manusia (biotin). Irawan dan Yeremias (2015) telah melakukan penelitian terkait pemanfaatan limbah serbuk kelapa (cocopeat) untuk media pertanaman. Dari penelitian ini ditemukan bahwa limbah serbuk kelapa (cocopeat) memiliki kemampuan memfiksasi air yang sangat kuat. Hal ini diperkuat dengan hasil penelitian Istomo dan Valentino (2012) yang juga menemukan bahwa limbah serbuk kelapa (cocopeat) mampu membatasi pergerakan air yang lebih besar akibat besarnya kandungan pori pori mikro. Sehingga hal tersebut menyebabkan ketersediaan air pada media tanam yang diberikan limbah serbuk kelapa (cocopeat) menjadi lebih tinggi. Penggunaan cocopeat diharapkan mampu menjadi solusi tingginya infiltrasi dan rendahnya daya pegang air pada lahan pasir pesisir pantai, sehingga air menjadi lebih tersedia. 
Limbah kotoran manusia dengan nama lain night soil selama ini dianggap sebagai limbah yang tidak berguna dan pembawa penyakit sehingga belum termanfaatkan secara optimal. Berdasarkan hasil penelitian Strauss (2000) limbah kotoran manusia mengandung unsur hara yang lebih tinggi dibandingkan limbah kotoran hewan. Setiap hari rata-rata kotoran yang dikeluarkan oleh manusia mengandung 90 gram bahan organik dengan kadar karbon sebesar 30 gram, nitrogen sebesar 10 - 12 gram, fosfor sebesar 2 gram dan kalium sebesar 3 gram. Penelitian mengenai aplikasi (limbah kotoran manusia) yang diberi nama lain biotin telah dilakukan oleh Zikri et al., (2017) menunjukkan bahwa tanaman hortikultura dan TOGA memiliki pertumbuhan dan hasil produksi yang optimal.

Tujuan penelitian ini adalah (1) memperoleh informasi perbaikan sifat kesuburan tanah dengan menggaplikasikan biococotin, (2) memperoleh informasi produktivitas lahan dan perbandingannya dengan kebiasaan petani dan (3) memperoleh informasi perbandingan pendapatan pertanian dengan menggunakan biococotin dan kebiasaan petani.

\section{BAHAN DAN METODA}

Pelaksanaan penelitian ini dilakukan selama tiga bulan yaitu pada bulan Juni hingga Agustus 2018 di Kuala Alam, Kelurahan Lempuing, Kecamatan Ratu Agung, Kota Bengkulu. Lokasi ini memiliki ketinggian 0-10 mdpl. Penelitian disusun dengan menggunakan Rancangan Acak Kelompok Lengkap (RAKL). Terdapat 4 perlakuan dan 4 ulangan sehingga didapatkan 16 petak percobaan. Petak percobaan dibuat dengan ukuran $1 \mathrm{~m}$ x $1 \mathrm{~m}$ dengan jarak tanam $15 \mathrm{~cm}$ x $20 \mathrm{~cm}$ sehingga didapatkan 30 tanaman perpetak. Taraf perlakuan yang digunakan adalah : P0 = NPK (tanpa pupuk kandang, $100 \mathrm{~kg}$ Urea, $100 \mathrm{~kg} \mathrm{SP} 3$ dan $75 \mathrm{~kg} \mathrm{KCl}$ per Ha) P1 = Pupuk Kotoran Ayam dan NPK (15 ton/ha Kotoran Ayam dan $50 \mathrm{~kg}$ Urea, 50 $\mathrm{kg} \mathrm{SP} 36$ dan $37.5 \mathrm{~kg} \mathrm{KCl}$ per $\mathrm{Ha}$ )

$\mathrm{P} 2=$ Bococotin dan NPK (15 ton/ha Biococotin dan $50 \mathrm{~kg}$ Urea, $50 \mathrm{~kg}$ SP36 dan $37.5 \mathrm{~kg} \mathrm{KCl}$ per $\mathrm{Ha}$ )

P3 = Pupuk Kotoran Ayam, Biococotin dan NPK (7,5 ton/ha Kotoran Ayam, 7,5 ton/ha Biococotin, $50 \mathrm{~kg}$ Urea, $50 \mathrm{~kg}$ SP36 dan $37.5 \mathrm{~kg} \mathrm{KCl}$ per $\mathrm{Ha}$ )

Pembuatan biococotin adalah dengan mencampurkan limbah kotoran manusia (biotin) dan limbah serbuk kelapa (cocopeat). Biotin didapatkan dari Instalasi Pengolahan Lumpur Tinja (IPLT) kota Bengkulu dan cocopeat yang digunakan adalah sabut kelapa yang telah digiling dan dihaluskan (berupa serbuk).

Survei tanah dilakukan untuk melihat kondisi lahan penelitian dan mengambil sampel tanah awal yang akan dianalisis di laboratorium. Lahan tersebut dibersihkan dari gulma kemudian dibentuk petakan dengan ukuran $1 \mathrm{~m}$ x $1 \mathrm{~m}$ dan diberikan papan kode perlakuan. Petakan kemudian diberikan perlakuan sesuai taraf perlakuan (perlakuan jumlah perlakuan tiap petak terlampir) kemudian di inkubasi selama 2 minggu. Sawi terlebih dahulu disemaikan dan dipindah tanamkan setelah berumur 10-15 hari.

Pemeliharaan terdiri pemupukan, penyiraman, pengendalian hama dan penyakit serta pengendalian gulma dengan penyuangan. Pemupukan dilakukan 2 kali selama musim tanam dengan dosis setengah dari perlakuan. Pemupukan pertama dilakukan saat dua hari sebelum tanam. Pemupukan kedua dilakukan saat umur tanaman setengah sebelum panen. Penyiraman dilakukan secara intensif pagi

https://doi.org/10.25077/jsolum.17.1.12-20.2020 
dan sore mengingat pasir memiliki daya pegang air yang rendah. Pengendalian gulma dilakukan dengan mencabuti jika ada yang tumbuh dan serangan hama penyakit dilakukan pengendalian jika ada serangan.

Parameter pertumbuhan tanaman diamati setiap satu minggu sekali setelah tanam hingga masa panen dengan melakukan pengukuran pada berbagai parameter pertumbuhan dan produksi tanaman.Pemanenan dilakukan setelah tanaman siap panen. Sawi dipanen 25-30 hari setelah dipindahkan. Tanaman hortikultura dipanen dengan cara mencabut lalu membersihkan akar dari tanah menggunakan air lalu dibilas hingga bersih. Pengumpulan data dilakukan dengan menganalisis tanah awal dan tanah setelah diberi perlakuan dan inkubasi. Selain itu juga diamati pertumbuhan dan produksi tanaman. Parameter yang diamati disampaikan pada tabel berikut.

Parameter pengamatan untuk sampel tanah setelah perlakuan terdiri atas : Nitrogen Total, Fosfor Tersedia, Kalium Tersedia, Karbon Organik, KTK, pH dan Kadar Air dan parameter pertumbuhan tanaman.

\section{HASIL DAN PEMBAHASAN}

Hasil analisis tanah pada tabel 1 menunjukkan bahwa tanah pasir pesisir pantai memiliki berbagai faktor pembatas, antara lain : $\mathrm{pH}$ yang basa, C-Organik, Nitrogen, Fosfor, Kalium dan Kapasitas Tukar Kation (KTK) yang tergolong rendah. Dari tabel terlihat bahwa pemberian perlakuan berupa pupuk organik kandang ayam, biococotin dan campuran kandang ayam dan biococotin dapat meningkatkan nilai-nilai parameter kesuburan tanah tersebut. Nilai $\mathrm{pH}$ terbaik pada perlakuan 1 (pupuk kandang ayam), C-Organik dan KTK terbaik pada perlakuan 3 (campuran pupuk kandang ayam dan biococotin) dan untuk kadar N, P dan $\mathrm{K}$ terbaik perlakuan 2 (biococotin). Beberapa hasil penelitian menunjukkan, kotoran manusia, yang dalam penelitian ini disebut dengan biococotin memiliki kandungan hara tertinggi dibandingkan dengan pupuk kotoran lainnya.

$$
\text { Penelitian Widowati }
$$

menunjukkan bahwa pemberian bokashi tinja 10 ton/ha meningkatkan nilai kapasitas tukar kation (KTK) sebesar $67,09 \%$, serapan $\mathrm{N}$ sebesar $121,86 \mathrm{mg}$ $\mathrm{N} / \mathrm{kg}$, sepatan $\mathrm{P}$ sebesar $13,21 \mathrm{mg} \mathrm{P} / \mathrm{kg}$ dan $\mathrm{K}$ sebesar 68,27 $\mathrm{mg} \mathrm{K} / \mathrm{kg}$.

Tabel 1. Hasil analisis tanah setelah pemberian perlakuan

\begin{tabular}{lcccc}
\hline \multicolumn{1}{c}{$\begin{array}{c}\text { Parameter } \\
\text { Pengamatan }\end{array}$} & \multicolumn{4}{c}{ Taraf Perlakuan } \\
\cline { 2 - 5 } $\mathrm{pH} \mathrm{H} \mathrm{H}_{2} \mathrm{O}$ & $\mathbf{P 0}$ & $\mathbf{P 1}$ & $\mathbf{P 2}$ & P3 \\
$\mathrm{C}-$ Organik $(\%)$ & 0.79 & 1,80 & 6,40 & 6,38 \\
$\mathrm{~N}(\%)$ & 0,021 & 0,07 & 1,48 & 2,17 \\
$\mathrm{P}(\mathrm{ppm})$ & 2,52 & 2,88 & 0,17 & 0,14 \\
$\mathrm{~K}(\mathrm{me} / 100 \mathrm{~g})$ & 2,52 & 6,47 & 20,13 & 12,22 \\
$\mathrm{KTK}\left(\mathrm{Cmol}^{(+)} / \mathrm{kg}\right)$ & 4,04 & 6,06 & 9,35 & 8,63 \\
\hline
\end{tabular}

Keterangan : P0 (NPK/Kontrol), P1 (NPK+Kotoran Ayam), P2 (NPK + Biococotin) dan P3 (NPK+ Kotoran Ayam + Biococootin) 
Penurunan $\mathrm{pH}$ dari basa menjadi mendekati netral disebabkan oleh adanya bahan organik yang mengandung asamorganik. Penelitian Anandyawati et al., (2017) pada media tanam pasir menunjukkan adanya penurunan $\mathrm{pH}$ media tanam karena asam-asam organik, baik yang dikeluarkan tanaman melalui eksudat akar dan juga asam organik yang terdapat pada bahan organik yang ditambahkan.

Pada Tabel 2 terlihat peningkatan tinggi tanaman pada setiap pengukuran. Pengukuran tinggi tanaman dilakukan pada saat tanaman berumur 7, 14, 21 dan 28 hari setelah tanam.Tinggi tanaman diukur dari batang yang berada di atas permukaan tanah sampai ujung daun terpanjang Dari tabel pertumbuhan tinggi terbaik adalah pada perlakuan P2 yaitu perlakuan biococotin dan NPK. Pada Tabel 3 terlihat peningkatan jumlah daun pada setiap pengukuran. Pengukuran jumlah daun dilakukan pada saat tanaman berumur 7, 14, 21 dan 28 hari setelah tanam. Dari tabel pertumbuhan jumlah daun terbaik adalah pada perlakuan P2 yaitu perlakuan biococotin dan NPK.

Tabel 2. Pengaruh perlakuan terhadap tinggi tanaman $(\mathrm{cm})$

\begin{tabular}{ccccc}
\hline \multirow{2}{*}{ Perlakuan } & \multicolumn{4}{c}{ Waktu Pengamatan $(\mathbf{H S T})$} \\
\cline { 2 - 5 } & $\mathbf{7}$ & $\mathbf{1 4}$ & $\mathbf{2 1}$ & $\mathbf{2 8}$ \\
\hline P0 & $7,38 \mathrm{a}$ & $11,68 \mathrm{a}$ & $23,80 \mathrm{a}$ & $30,13 \mathrm{a}$ \\
P1 & $11,85 \mathrm{a}$ & $19,4 \mathrm{a}$ & $27,95 \mathrm{~b}$ & $34,00 \mathrm{~b}$ \\
P2 & $17,85 \mathrm{~b}$ & $25,63 \mathrm{~b}$ & $32,73 \mathrm{~b}$ & $36,63 \mathrm{~b}$ \\
P3 & $13,58 \mathrm{a}$ & $19,88 \mathrm{a}$ & $25,80 \mathrm{a}$ & $27,25 \mathrm{a}$ \\
\hline
\end{tabular}

Keterangan : P0 (NPK/Kontrol), P1 (NPK+Kotoran Ayam), P2 (NPK + Biococotin) dan P3 (NPK+ Kotoran Ayam + Biococootin)

Tabel 3. Pengaruh perlakuan terhadap jumlah daun

\begin{tabular}{ccccc}
\hline \multirow{2}{*}{ Perlakuan } & \multicolumn{4}{c}{ Waktu Pengamatan (HST) } \\
\cline { 2 - 5 } & $\mathbf{7}$ & $\mathbf{1 4}$ & $\mathbf{2 1}$ & $\mathbf{2 8}$ \\
\hline P0 & $4,75 \mathrm{a}$ & $5,50 \mathrm{a}$ & $9,50 \mathrm{a}$ & $10,00 \mathrm{a}$ \\
P1 & $5,75 \mathrm{a}$ & $8,25 \mathrm{ab}$ & $11,25 \mathrm{a}$ & $15,75 \mathrm{a}$ \\
P2 & $6,00 \mathrm{~b}$ & $10,00 \mathrm{~b}$ & $12,50 \mathrm{a}$ & $18,50 \mathrm{~b}$ \\
P3 & $6,00 \mathrm{~b}$ & $7,50 \mathrm{ab}$ & $12,75 \mathrm{a}$ & $15,50 \mathrm{ab}$ \\
\hline
\end{tabular}

Keterangan : P0 (NPK/Kontrol), P1 (NPK+Kotoran Ayam), P2 (NPK + Biococotin) dan P3 (NPK+ Kotoran Ayam + Biococootin).

Pada Tabel 4 terlihat peningkatan panjang daun terpanjang pada setiap pengukuran. Pengukuran panjang daun terpanjang dilakukan pada saat tanaman berumur 7, 14, 21 dan 28 hari setelah tanam. Dari tabel panjang daun terpanjang terbaik adalah pada perlakuan P2 yaitu perlakuan biococotin dan NPK

Pada Tabel 5 terlihat peningkatan lebar daun terpanjang pada setiap pengukuran. Pengukuran lebar daun terpanjang dilakukan pada saat tanaman berumur 7, 14, 21 dan 28 hari setelah tanam. Dari tabel lebar daun terpanjang terbaik adalah pada perlakuan P2 yaitu perlakuan biococotin dan NPK.

Pada Tabel 6 terlihat adanya pengaruh perlakuan terhadap klorifi atau zat hijau daun, panjang akar, bobot perbatang dan produksi per hektar 
menunjukkan perlakuan P2 merupakan perlakuan dengan hasil yang terbaik.

Tabel 4. Pengaruh perlakuan terhadap panjang daun terpanjang $(\mathrm{cm})$

\begin{tabular}{cllll}
\hline \multirow{2}{*}{ Perlakuan } & \multicolumn{4}{c}{ Waktu Pengamatan (HST) } \\
\cline { 2 - 5 } & \multicolumn{1}{|c}{$\mathbf{1 4}$} & $\mathbf{2 1}$ & $\mathbf{2 8}$ \\
\hline P0 & $5,38 \mathrm{a}$ & $8,00 \mathrm{a}$ & $11,43 \mathrm{a}$ & $13,25 \mathrm{ab}$ \\
P1 & $6,5 \mathrm{ab}$ & $9,975 \mathrm{a}$ & $15,6 \mathrm{~b}$ & $17,75 \mathrm{ab}$ \\
P2 & $10,00 \mathrm{~b}$ & $12,13 \mathrm{~b}$ & $16,25 \mathrm{~b}$ & $17,50 \mathrm{~b}$ \\
P3 & $8,25 \mathrm{a}$ & $10,73 \mathrm{a}$ & $15,78 \mathrm{a}$ & $15,25 \mathrm{a}$ \\
\hline
\end{tabular}

Keterangan : P0 (NPK/Kontrol), P1 (NPK+Kotoran Ayam), P2 (NPK + Biococotin) dan P3 (NPK+ Kotoran Ayam + Biococootin).

Tabel 5. Pengaruh perlakuan terhadap lebar daun $(\mathrm{cm})$

\begin{tabular}{ccccc}
\hline \multirow{2}{*}{ Perlakuan } & \multicolumn{4}{c}{ Waktu Pengamatan $(\mathbf{H S T})$} \\
\cline { 2 - 5 } & $\mathbf{7}$ & $\mathbf{1 4}$ & $\mathbf{2 1}$ & \multicolumn{1}{c}{$\mathbf{2 8}$} \\
\hline P0 & $3,55 \mathrm{a}$ & $6,98 \mathrm{a}$ & $7,70 \mathrm{a}$ & $7,75 \mathrm{a}$ \\
P1 & $4,45 \mathrm{~b}$ & $6,43 \mathrm{~b}$ & $9,25 \mathrm{~b}$ & $10,63 \mathrm{bc}$ \\
P2 & $6,50 \mathrm{c}$ & $7,63 \mathrm{c}$ & $10,10 \mathrm{c}$ & $10,38 \mathrm{c}$ \\
P3 & $5,65 \mathrm{~b}$ & $6,88 \mathrm{~b}$ & 9,15 & $9,25 \mathrm{~b}$ \\
\hline
\end{tabular}

Keterangan : SW0 (NPK/Kontrol), SW1 (NPK+Kotoran Ayam), SW2 (NPK + Biococotin) SW3 (NPK+ Kotoran Ayam + Biococootin)

Tabel 6. Pengaruh perlakuan klorofil, panjang akar, bobot perbatang dan produksi per ha

\begin{tabular}{ccccc}
\hline Perlakuan & Klorofil & Panjang Akar & Bobot per Batang & Produksi per Ha \\
\hline P0 & 13,55 & 9,75 & 13,501 & 8,10 \\
P1 & 17,05 & 14,5 & 43,518 & 26,11 \\
P2 & 30,9 & 14,5 & 44,024 & 26,41 \\
P3 & 16,825 & 12,25 & 23,68 & 14,21 \\
\hline
\end{tabular}

Keterangan : SW0 (NPK/Kontrol), SW1 (NPK+Kotoran Ayam), SW2 (NPK + Biococotin) SW3 (NPK+ Kotoran Ayam + Biococootin)

Parameter pertumbuhan yang diukur dan diamati dalam penelitian antara lain adalah : tinggi tanaman, jumlah daun, panjang daun terpanjang dan lebar daun terpanjang. Parameter parameter pertumbuhan tersebut menunjukkan hasil terbaik pada perlakuan P2 dengan menggunakan biococotin dan NPK. Hal ini dikarenakan penambahan biococotin dan NPK dapat meningkatkan kandungan hara tersedia tanah terutama $\mathrm{N}, \mathrm{P}$ dan $\mathrm{K}$ sebagaimana ditampilkan pada tabel 1 . Nitrogen dibutuhkan tanaman untuk pertumbuhan dan perlakuan P2 dapat menyediakan nitrogen sejumlah yang dibutuhkan oleh tanaman sawi untuk tumbuh dan berkembang. Penelitian Novizan (2002) menemukan bahwa pertumbuhan dan perkembangan tanaman sangat dipengaruhi oleh ketersediann unsur Nitrogen. Kandungan nitrogen yang cukup tersedia menjadikan warna daun lebih hijau segar karena kandungan klorofil (zat hijau daun) terbentuk lebih banyak dan memperbesar tangkapan sinar matahari dalam proses fotosintesis. Nitrogen juga membentu percepatan tumbuh tanaman seperti: tinggi, jumlah daun, cabang, anakan dan sebagainya. Nitrogen dibutuhkan oleh semua jenis tanaman dan 
membantu proses penambahan kandungan protein tanaman, Optimalisasi ketersediaan nitrogen di dalam tanah dapat meningkatkan persentasi tumbuh dan kembang tanaman, memperbanyak sintesis protein, pembentukan klorofil (zat hijau daun) yang mempengaruhi warna daun menjadi lebih gelap dan meningkatkan perbandingan pucuk akar.

Penelitian Dwidjosaputro 1990

dalam Erawan et. al., 2013) mengemukakan bahwa nitrogen merupakan unsur hara esensial dan zat utama yang menyusun protoplasma serta banyak terdapat dalam jaringan titik tumbuh yang membantu sel dalam melakukan pembelahan dan perpanjangan terutama pada fase pertumbuhan vegetatif.

Selain parameter pertumbuhan tanaman, juga diamati parameter produksi yaitu dengan mengamati bobot pertanaman dan bobot per Ha. Parameter parameter produksi tersebut menunjukkan hasil terbaik pada perlakuan P2 dengan menggunakan biococotin dan NPK. Hal ini dikarenakan tercukupinya kebutuhan unsur hara tanaman yang diperlukan untuk tumbuh dan berkembang. Menurut Gardner et al., 1991 (dalam Erawan et al., 2013) terdapat dua status hara dalam jaringan tanaman dan pertumbuhan tanaman yaitu, kondisi defisiensi dan tersedia, yang berakibat terhadap produksi tanaman. Penambahan hara akan mengakibatkan peningkatan produksi yaitu dengan meningkatnya berat tanaman pada status defisiensi. Sedangkan penambahan hara mengakibatkan peningkatan kadar unsur hara dalam jaringan tanaman tetapi tidak ada peningkatan produksi panen pada status hara cukup.

\section{KESIMPULAN}

Pemberian biococotin pada lahan pasir pesisir pantai menurunkan $\mathrm{pH}$ yang basa mendekati netral, meningkatkan kadar N, P, K, C-Organik dan kapasitas tukar kation.pH mengalami penurunan dari 7,20 menjad 6,40. Kadar $\mathrm{N}$ meningkat dari $0,021 \%$ menjadi $0,17 \%$, kadar $\mathrm{P}$ meningkat dari 2,52 ppm menjadi 20,13 ppm, kadar K meningkat dari 2,52 me/100g menjadi 9,35 me/100 g dan KTK meningkat dari 4,04 $\mathrm{Cmol}(+) / \mathrm{kg}$ menjadi $7,07 \mathrm{Cmol}(+) / \mathrm{kg}$. Parameter pertumbuhan (tinggi tanaman, jumlah daun, panjang daun terpanjang dan lebar daun terpanjang) terbaik rata-rata ditunjukkan oleh perlakuan 2 yaitu setengah dosis NPK dan Biococotin. Bobot pertanaman dan hasil produksi per ha terbaik rata-rata ditunjukkan oleh perlakuan 2 yaitu setengah dosis NPK dan Biococotin yaitu 44,03 gram/tanaman dan 26,41 ton/ha.

\section{UCAPAN TERIMAKASIH}

Terimakasih disampaikan kepada Lembaga Penelitian dan Pengabdian kepada Masyarakat (LPPM) Universitas Bengkulu atas batuan dana penelitian skim penelitian pembinaan tahun 2018 .

\section{DAFTAR PUSTAKA}

Anandyawati, S. Anwar B. Nugroho, R. Widyastuti dan S. Sabiham. 2017. Study of Root Exudate Organic Acids and Microbial Population in the Rhizosphereof Oil Palm Seedling. J TropSoils. Vol. 22(1):29-36.

Aqil, M. 2002. Pengaruh Laju Irigasi Serta Dosis Bahan Pengkondisi Tanah terhadap Tingkat Penahanan Lengas Tanah dan Produksi Tanaman Pangan dan Hortikultura pada Tamah Pasir Bul. Agron. Vol.30(2): $31-38$.

Cornell, S.E., T.D. Jickells, J.N. Cape, A.P. Rowland, R.A. Duce. 2003. 
Organic Nitrogen Depositionon Land and Coastal Environments: A Review of Methods and Data. Atmospheric Environment. vol 37(16): 2173-2191.

DPU [Departemen Pekerjaan Umun]. 2000. Buku Penyelidikan Tanah dan Tanaman : Perencanaan Jaringan Irigasi Lahan Pantai Provinsi DIY. PT Firama Citra Utama : Yogyakarta.

Erawan. D, Y. Wa Ode dan Bahrun. 2013. Pertumbuhan dan Hasil Tanaman Sawi (Brassicajuncea, L.) pada Berbagai Dosis Pupuk Urea, Jurnal Agroteknos, 3 (1) : 19-25.

Irawan, A., K. Yeremias. (2015). Pemanfaatan Cocopeat dan Arang Sekam Padi sebagai Media Tanam Bibit Cempaka Wasian (Elmerrilia ovalis). Prosiding Seminar Nasional Masyarakat Biodiversitas Indonesia, Vol. 1(4): 805-808.

Istomo, N. Valentino. 2012. Pengaruh perlakuan kombinasi media terhadap pertumbuhan anakan tumih (Combretocarpusrotundatus (Miq.) Danser). Jurnal Silvikultur Tropika. Vol. 3(2): 81-84.

Kementerian Pertanian. 2015. Outlook Komoditas Pertanian Subsektor Tanaman Pangan Jagung. Jakarta: Pusdatin Kementerian Pertanian.

Lasabuda, R. 2013. Pembangunan Wilayah Pesisir Dan Lautan DalamPerspektif Negara Kepulauan Republik Indonesia. Jurna IIlmiah Platax. Vol. I(2): 92-101.

Novizan. 2002. Pupuk Pemupukan Yang Efektif. Agromedia. Jakarta.
Oke, T.R. 1978. Bondary Layer Climate. London : Menthmenand Co Ltd.

Pemerintah Provinsi Bengkulu. 2015. Geologi Pemerintah Provinsi Bengkulu.

http://bengkuluprov.go.id/. Diakses Juni 2018.

Rajiman, P. Yudono, E. Sulistyaningsih, E. Han-udin, 2008. Pengaruh Pembenah Tanah Terhadap Sifat Fisika Tanah dan Hasil Bawang Merah Pada Lahan Pasir Pantai Bugel Kabupaten Kulon Progo. J. Agrin. Vol 12(1): 67-77.

Rosenberg, N.J. 1974. Microclimate the Biological Enviroment. London : Longman.

Shi, Z, Li Y, R.C Wang, F. Makeschine. 2005. Assessment of Temporal and Spatial Variability of Soil Salinity in a Coastal Saline Field. Environmental Geology. vol 48(2): 171-178.

Sitorus, SRP, E. Kusumastuti, L.N. Badri. 2008. Karakteristik dan Teknik Rehabilitasi Lahan Pasca Penambangan Timah di Pulau Bangka dan Singkep. Jurnal Tanah dan Iklim. Vol 27:57-74.

Sumardi. 2008. Prinsip Silvikultur Reforestasi dalam Rehabilitasi Formasi Gumuk Pasir di Kawasan Pantai Kebumen. Prosiding Seminar Nasional Silvikultur Rehabilitasi Lahan: Pengembangan Strategi untuk Mengendalikan Tingginya Laju Degradasi Hutan. 24-25 November 2008. Yogyakarta: Fakultas Kehutanan, Universitas Gadjah Mada. hal. 58-65. 
Sunardi dan Y. Sarjono. 2007. Penentuan Kandungan Unsur Makro pada Lahan Pasir Pantai Samas Bantul dengan Metode Analisis Aktivasi Neutron (AAN). Prosiding PPIPDIPTN. 10 Juli 2007. Yogyakarta:

Pusat Teknologi Akselerator dan Proses Bahan, Badan Tenaga Nuklir Nasional (BATAN). hal. 123-129.

Strauss, M. 2000. Human Waste (ExcretaandWastewater) Reuse. EAWAG/SANDEC, Duebendorf, Switzerland,
Widowati. 2007. Serapan Nitrogen, Fosfor dan Kalium Bokhasi Tinja oleh Tanaman Jagung. Buana Sains. Vol 7 (1) : 21-26.

Zikri, M., S. Eko dan S.P Basuki. 2017. Aplikasi Modifikasi Biotin Berbagai varian untuk Penghijauan Pesisir Pantai dan Tanaman Obat Keluarga (TOGA) di Kelurahan Berkas kota Bengkulu. Jurnal Dharma Rafflesia Vol. 2(25): 1-12 